who found that reduction of the prosthetic group by alanin (which stops as soon as the bound prosthetic group is reduced because the reduction product sticks to the protein) proceeds only until one mol per $100,000 \mathrm{gm}$. of the (not quite pure) protein has reacted.

${ }^{1}$ Broda, E. E., Goodeve, C. F., and Lythgoe, R. J., J. Physiol., 98, 397 (1940).'

Keilin, D., and Mann, T., NATURE, 143, 23 (1939).

' Keilin, D., and Mann, T., Biochem. J., 34, 1163 (1940).

- Green, D. E., "The Mechanism of Biological Oxidations" (Cambridge, 1940 ), p. 124.

- Pedersen, K. O., and Heidelberger M., J. Gen. Physiol., 19, 95 (1935).
${ }^{6}$ Dalton, H. R., and Nelson, J. M., J. Amer. Chem. Soc., 61, 2469 (1939).

' cf. Kubowitz, F., Biochem. Z., 299, 51 (1938).

${ }^{8}$ Lovell-Janison, P. L., and Nelson, J. M., J. Amer. Chem. Soc., 62, 1409 (1940).

- Straub, F. B., Biochem. J., 33, 787 (1939).

${ }^{10}$ Corran, H. S., Dewan, J. G., Gordon, A. H., and Green, D. E., Biochem. J., 33, 1694 (1939).

11 Philpot, J. St. L., Biochem. J., 83, 1707 (1939).

12 Sumner, J. B., and Dounce, A. L., J. Biol. Chem., 127, 439 (1939).

${ }^{1}$ cf. Svedberg, Th., and Pedersen, K. O., "The Ultracentrifuge". Oxford University Press (1940).

14 See "containing weights", Cohn, E. J., Physiol. Rev., 5, 349 (1925).

${ }^{15}$ Warburg, O., and Christian, W., Biochem. Z., 298, 150 (1938).

${ }^{16}$ Negelein, E., and Brömel, H., Biochem. Z., 300, 225 (1939).

\title{
ETHNOLOGY OF THE LAU ISLANDS, FIJI
}

$\mathrm{T}$ ETeat interest held by the Lau islands for the ethnologist lies in the fact that they are situated between Fiji and Tonga, on the border where Melanesia and Polynesia meet. They had been subjected, therefore, to different impacts, both physical and cultural, even before the advent of Western civilization. For this reason the author of a recent paper* chose a group of islands in southern Lau which owing to its isolation and lack of valuable natural resources had been left comparatively untouched by Western influences, and on one of these, Kambara, she lived for five months making an intensive study of its culture. Owing to lack of time she was unable to devote much attention to material culture and concentrated rather on the social system as being more evanescent.

After a short account of the physical types and the geography of the island group, including a census of the chief village of Kambara, the author gives a full description of the social organization of the people. This is very complicated owing to the different influences that have impinged on the islands, but she has worked out the different social groups. The largest unit, the phratry, consists of groups of clans with the same mythical ancestor or group of ancestors. The clans are divided into subclans and these again into families or households. Through all these runs a deep-seated and elaborate system of rank; not only each phratry, clan, sub* Bernice P. Bishop Museum. Bulletin 162: "Southern Lau Fiji: an Ethnography." By Laura Thompson. Pp. iii $+228+5$ pl. (Honolulu, 1940). clan, family and individual, but also each village and chiefdom holds a different rank in the scheme. This is all clearly set out, and in subsequent sections marriage and relationship are discussed, followed by an account of the ceremonial usages and the economic life and material culture of the islands. The author also found time to excavate some archæological sites, principally fortresses on the various islands.

In her conclusion the author suggests that Lauan culture consists of three complexes: that of its own aboriginal (Melanesian) inhabitants, which is similar to that of the low Fijian culture of western Viti Levu. Some three hundred years ago, according to genealogies and tradition, a group of immigrants from eastern Viti Levu introduced a highly organized. culture of a Polynesian type with a complicated system of rank, and they also increased production and developed industry to a high degree. The third impact came from the west with Tongan contact in the late "prehistoric" period. Its outstanding contributions were the concept of divine chieftainship with attendant ceremonial, of kava drinking and dancing, while on the material side came the introduction of the western Polynesian oval house and the technique of pasting tapa into long sheets. Thus Lauan culture is truly marginal and presents a unique fusion of Melanesian and early and late Polynesian complexes.

The bulletin is illustrated by maps, tables and photographs, and contains a bibliography and complete index.

\section{SOUTH-EASTERN UNION OF SCIENTIFIC SOCIETIES}

\section{Annual Congress}

T HE South-Eastern Union of Scientific Societies has, for the second time, been obliged to curtail its annual congress to a single day of sessions and excursions; this was held at Kingston-upon-Thames on July 26 .

A representative assembly to transact the business of the seventy constituent societies was held during the forenoon, in the Queen Elizabeth Grammar School. Dr. W. E. St. Lawrence Finny, who has been mayor of the Royal Borough of Kingston no fewer than seven times, was elected president for 1941-42 ; in recent years he has served the Union as president of the Archæological Section.

"The Church of the Saxon Coronations at Kingston" was the title of Dr. Finny's presidential address. $\mathrm{He}$ described the ancient form of the Coronation Service, tracing its origin to the Court of Charlemagne, and showed lantern slides of such evidence as now exists of the church in which the Saxon kings must have been crowned. At Kingston the principal 
exhibit is the original Coronation Stone of which the early history is unknown, but a coin is preserved showing Dubnovilaunus, a king of Kent, seated upon a stone of similar size and shape. Another local relic is a fragment of a Saxon commemorative cross bearing an interlaced design of a type not found elsewhere south of the Midlands. In the Lady Chapel of the Coronations there used to be fourteenthcentury paintings of five of the Saxon kings crowned at Kingston as well as one of King John : it was the latter who gave the first extant charter to Kingston, the oldest of the three 'Royal Boroughs'- the other two being Windsor and Kensington. The original paintings upon wooden panels of these kings were accidentally discovered in 1813 during the renovation of Baston Manor House in Kent. One of these panels is now preserved in the hall of the Society of Antiquaries, and its Latin inscription gives conclusive proof that Athelstan was crowned at Kingston.

Dr. Finny's address had been preceded by separate sessions for business and the reading of sectional addresses, which will appear later in an abbreviated volume of the South-Eastern Naturalist and Antiquary (vol. 46).

The address to the Archæological Section was given by Edward Yates, on "The Early History of Hampton Court Palace". A feature of the Palace is the ease with which the buildings can be dated by the character of the brickwork and fenestration. The address to the Botanical Section was given by Dr. J. Ramsbottom, who spoke on "The Preservation of our Flora". The address to the Geological Section was delivered by Dr. R. L. Sherlock on "The Red Rocks as Indicators of Past Climates". In view of the Thames swan upping having been completed at Henley the previous day, it was appropriate that the presidential address to the Zoological Section should be by N. F. Ticehurst, upon "The Mute Swan on the Thames", illustrated with lantern slides of the old local swan-marks and upping ceremonies. Owing to lack of time, some further papers were taken as read. The Zoological Section papers had been prepared in the form of a Bulletin (No. 76). It includes a short paper by Miss $Z$. V. Waloff, of the Imperial Institute of Entomology, on "The Migratory Locust in the British Isles" and a "Preliminary Note on Dragonfly Migration" as an appendix to the annual report of the Insect Immigration Committee. The latter showed that the regular migration was upon a small scale comparable with that of 1937, and with a similar invasion of the large white butterfly, Pieris brassicoe $\mathrm{L}$., the subsequent larvæ of which did considerable damage in market gardens (see Entomologist, 74, 54-62).

Dr. Finny conducted a party to Lovekyn's four. teenth-century chantry chapel and to other places of local antiquarian interest. Geologists werit to Mickleham to examine fresh exposures in the Chalk recently cut for the Dorking by-pass road; a junction of the Middle and Upper Chalk here exhibits fossils of the Terebratulina Iata and Holaster planus zones. R. V. Melville described the history of the Mole Gap and showed a fine swallow-hole near Mickleham Church.

No definite arrangements for the 1942 Congress were announced; but, in view of its jubilee, it was suggested that a suitable centre for an abbreviated Congress would be the Haslemere Educational Museum.

\section{APPOINTMENTS VACANT}

APPLICATHONS are invited for the following appointments on or before the dates mentioned:

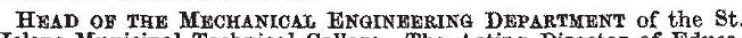
Helens Municipal Technical Collego-The Acting Director of Education, Education Office, St. Helens (August 21).

Iacturer in Agricultural Chemintry-The Registrar, King's College, Newcastle-upon-Tyne (August 26).

HEAD OF THE ELECTRICAI ENGINEERING DEPARTMENT -The Secretary and Registrar, Robert Gordon's Technical College, Aberdeen (August 30).

PRINCIPAI OF THF SCUNTHORPE MODKRN AND TECHNICAL SCHOOL -The Director of Education, County Offices, Lincoln (September 1). Grade II(B) LeCTORER IN THE Department OF MEchanioal Engingariva-The Secretary, The University, Edmund Street, Birmingham 3 (September 6).

College Librarian (Woman)-The Secretary, Bedford College for Women, Regent's Park, London, N.W.1 (September 13).

Professor of Mathromatics-The Registrar, University College of Swansea, Singleton Park, Swansea (September 13).

GRADUATH IN AGRICULTURAI OR VETERINARY SCIENCE, OR ZOOLOGY, OR Phrsionogr-The Deputy Director, Imperial Bureau of Anima burgh 9 (September 15).

LEOTURER IN GNGINEERING SubJeors at the Rotherham College of Technology and Art-The Director of Education, Education Offices, Rotherham.

Prysicist to undertake work on Stereotyping Flongs--The Director of Research, Printing and Allied Trades Research Association, 101 Princes Gardens, London, W.3.

LAND DRATNAGE OFFICER to the Wiltshire War Agricultural Executive Committee--The Chief Executive Officer, Agricultural Department, County Hall, Trowbridge.

\section{REPORTS AND OTHER PUBLICATIONS}

\author{
(not included in the monthly Books Supplement) \\ Great Britain and Ireland
}

British Rubber Producers' Research Association. Publication No. 9: The Kinetics of the Polymerization of Isoprene on Sodium Surfaces. By J. L. Bolland. Pp. 20. Publication No. 10: The Proteins Rubber brasiliensis, 2: Analysis of a Product isolated from crepe dueers'. By G. R. Tristram. Pp. 4. (London: British Rubber Pro-

Royal Meteorological Society. Bibliography of Meteorological Literature. Prepared by the Royal Meteorological Society with the collaboration of the Meteorological Office. Vol. 4, No. 10 (JulyDecember 1940). Pp. ii +489-504. (London: Royal Meteorological
Society.) 2s. 6d.

\section{Other Countries}

United States Department of Commerce: Weather Bureau. Monthly Weather Review, Supplement No. 44: Fifty Years' Weather in Kansas City, Mo., 1889-1938. By Andrew M. Hamrick and Howard H. Martin. (W.B. No.1316.) Pp. ili +53. (Washington, D.C.: Government Printing Office.) 20 cents.

U.S. Office of Education: Federal Security Agency. Pamphlet, No. 93: Trends in Industrial Arts. By Maris M. Proffitt. Pp. iv +20 (Washington, D.C. : Government, Printing Office.) 5 cents, [307

U. S. Department, of Agriculture. Cireular No. 600: Mortality of the Apple Maggot in Fruit held in Cold Storage. By $\dot{P} . J$. Chapman and A. D. Hess. Pp. 10. 5 cents. Circular No. 602 : Field Infestation by Insects that injure Rice in Storage. By W. A. Douglas. Pp. 8. 5 cents. Farmers' Bulletin No. 1566: The Sorghum Midge, with Suggestions for Control. Originally prepared by C, H. Gable, W. A. Baker and L. C. Woodruff, and slightly revised by $\mathrm{E}$. V. Walter. $\mathrm{Pp}$. ii +10 . 5 cents. Farmers' Bulletin No. 1860 : Gladiolus Diseases and Insects. By Lucia McCulloch and C. A. Weigel. Pp. ii +18.5 some Grasshoppers of Economic Importance on the Great Plains. By Robert, L. Shotwell. Pp. 48. 20 cents. (Washington, D.C. : Government, Printing office.)

Henry Lester Institute of Medical Research. Annual Report, 1940. Pp. $60+3$ plates. (Shanghai: Henry Lester Institute of Medical Research.) [31\%

South Australia. Annual Report of the Director of Mines and Government Geologist for $1939 . \quad P p .6$. (Adelaide: Government
Printer.)

South Australia : Department of Mines. Mining Review for the Half-Year ended 30th June 1940. (No, 72.) Pp 95. (Adelaide Government Printer.)

Editorial and Publishing Offices

MACMILLAN \& CO., LTD.

ST. MARTIN'S STREET, LONDON, W.C.2.

Telephone: Whitehail 8831 Telegraphic Address: Phusis Lesquare London Advertisements should be addressed to

T. G. Scott \& Son, Led., Three Gables, London Road, Merstham, Surrey Telephone: Merstham 316

The annual subseription rate is $\$ 4100$, payabie in advance, Inland or Abroad All rights reserved. Registered as a Newspaper at the General Post Office 